\title{
Nitrogen dynamics in Amazon forest and pasture soils measured by ${ }^{15} \mathrm{~N}$ pool dilution
}

\author{
Christopher Neill ${ }^{\mathrm{a}, *}$, Marisa C. Piccolo ${ }^{\mathrm{b}}$, Jerry M. Melillo ${ }^{\mathrm{a}}$, Paul A. Steudler ${ }^{\mathrm{a}}$, \\ Carlos C. Cerri ${ }^{\mathrm{b}}$ \\ ${ }^{a}$ The Ecosystems Center, Marine Biological Laboratory, Woods Hole, MA 02543, USA \\ ${ }^{\mathrm{b}}$ Centro de Energia Nuclear na Agricultura, Avenida Centenário 303, Caixa Postal 96, CEP 13416000, Piracicaba, SP, Brazil
}

Accepted 20 September 1998

\begin{abstract}
Clearing tropical forests of the Amazon Basin for pasture alters rates of soil nitrogen cycling. Previous studies have shown that rates of soil net $\mathrm{N}$ mineralization and net nitrification are lower in established pastures than in forests. We compared soil inorganic $\mathrm{N}$ concentrations, rates of net and gross mineralization and net and gross nitrification in a chronosequence and an experimental slash-and-burn plot in Rondônia. Soils of pastures 4, 10 and 21-yr-old contained $\mathrm{more}^{\mathrm{NH}_{4}^{+}}$and less $\mathrm{NO}_{3}^{-}$than soils of forest. Soil $\mathrm{NH}_{4}^{+}$and $\mathrm{NO}_{3}^{-}$concentrations were elevated for 2 months after burning but were similar to pools in the forest after 8.5 months. Rates of net $\mathrm{N}$ mineralization and net nitrification decreased from forest to 21-yr-old pasture. Rates of gross $\mathrm{N}$ mineralization were similar in forest, 4- and 10-yr-old pasture then declined in 21-yr-old pasture. These findings indicate that when forests are converted to pasture, soil $\mathrm{N}$ turnover is maintained for a period of a decade or longer, but $\mathrm{N}$ turnover eventually slows in old pastures. As older pastures come to dominate deforested regions of the Amazon, the total $\mathrm{N}$ cycled in soils of the region is likely to decrease, but not as quickly as studies based on net mineralization and net nitrification alone would indicate. (C) 1999 Elsevier Science Ltd. All rights reserved.
\end{abstract}

\section{Introduction}

Clearing of tropical forest can have important effects on soil physical and chemical characteristics, long term soil storage of carbon and soil cycling of mineral nutrients. The world's highest rates of clearing occur in the Brazilian Amazon Basin, where 11,000-29,000 km² of forest are cleared each year, primarily for cattle pastures (INPE, 1998). Understanding the changes to soil biogeochemistry that influence soil fertility after clearing will be important for implementing effective management of pasture agriculture and for predicting the regional ecological consequences of deforestation.

The replacement of forest vegetation with grasses and the maintenance of cattle pastures can influence rates of soil $\mathrm{N}$ turnover. Two patterns of changes of $\mathrm{N}$ turnover following forest clearing and pasture creation are apparent from previous studies. First, rates of net

\footnotetext{
* Corresponding author. Tel.: + 1-508-289-7481; fax: + 1-508-4571548; e-mail: cneill@mbl.edu.
}

mineralization and net nitrification are consistently lower in soils of pastures $3 \mathrm{yr}$ old or older than in soils of the forests from which they were created (Reiners et al., 1994; Neill et al., 1995, 1997; Verchot, pers. comm.). In the Amazon, this pattern occurs over a wide area on Oxisols and Ultisols (Neill et al., 1997). Second, although rates of net $\mathrm{N}$ mineralization and net nitrification are lower in established pastures, inorganic $\mathrm{N}$ pools, net mineralization rates and net nitrification rates may be elevated in the immediate postclearing period (Matson et al., 1987; Montagnini and Buschbacher, 1989). We currently interpret these patterns to indicate that after a brief period of elevated $\mathrm{N}$ turnover following the disturbance of clearing, $\mathrm{N}$ turnover gradually declines as pastures age.

Net $\mathrm{N}$ mineralization provides an index of plant available $\mathrm{N}$ in many systems (Nadelhoffer et al., 1983), but does not reflect the total amount of $\mathrm{N}$ cycling between organic matter and soil inorganic N. Gross rates of $\mathrm{N}$ mineralization and nitrification measured by ${ }^{15} \mathrm{~N}$ dilution (Davidson et al., 1991) provide measured of the total amount of $\mathrm{N}$ mineralized and nitrified that 
can be contrasted with net $\mathrm{N}$ transformations. In this study, we compared rates of gross mineralization and nitrification with rates of net mineralization and nitrification in soils of a reference forest and pastures of different ages in the Brazilian Amazon state of Rondônia where we have measured net rates over an annual cycle (Neill et al., 1995). We also contrasted gross and net $\mathrm{N}$ transformations before and after we created a new pasture by slashing and burning an area of the reference forest. Our objectives were to determine: (1) if patterns of gross $\mathrm{N}$ mineralization or gross nitrification rates were similar to patterns of net $\mathrm{N}$ mineralization and net nitrification rates in forest, newly-created pasture and established pasture, and (2) if rates of gross mineralization or gross nitrification were sustained in older pastures even as net rates declined. We use these results to evaluate our current interpretation of patterns of $\mathrm{N}$ cycling after forest clearing and to suggest the consequences of widespread clearing for pastures for regional $\mathrm{N}$ cycling.

\section{Methods}

Study areas were a chronosequence of forest and pastures of different ages and a 3 ha plot of forest that was sampled before and after it was cleared and planted to pasture. All sites were at Fazenda (Ranch) Nova Vida at km 472 of highway BR-364, $50 \mathrm{~km}$ southeast of Ariquemes $\left(10^{\circ} 30^{\prime} \mathrm{S}, 62^{\circ} 30^{\prime} \mathrm{W}\right)$ in central Rondônia. The chronosequence had pastures of ages of 4, 10 and $21 \mathrm{yr}$, which were identified from ranch records and satellite images. Forest vegetation was typical of the open, humid tropical forests of Rondônia, with large numbers of palms. Selective logging in the forest removed about 3-4 trees $\mathrm{ha}^{-1}$ between 1987 and 1990. All pastures were created in a similar manner by cutting brush during March, cutting trees during June and July, burning slash following the beginning of the rainy season in September or early October, and planting grasses following burning. The 4- and 21-yr-old pastures were dominated by Brachiaria brizantha [Hochst] Stapf. and the 10-yr-old pasture contained B. brizantha and Panicum maximum [Rendle] Schweickt. All pastures were actively grazed at an average rate of about 1 animal $\mathrm{ha}^{-1}$. Neither mechanized agricultural practices nor chemical fertilizers were used on any of the pastures. Pastures were burned every $4-10 \mathrm{yr}$ to control weeds. The new pasture was cut from the forest of the chronosequence in June 1994, burned in September 1994 and planted with $B$. brizantha in January 1995. All soils were Kandiudults with clay contents of $23-35 \%$ at $0-10$ $\mathrm{cm}$. The climate of the region is humid tropical, with a dry season from May to September. Annual rainfall is $2.2 \mathrm{~m}$, annual mean daily temperature is $25.6^{\circ} \mathrm{C}$, and mean daily temperature for the warmest and coolest months varies less than $5^{\circ} \mathrm{C}$ (Bastos and Diniz, 1982).

Soils were characterized for $\mathrm{pH}$, bulk density, total $\mathrm{C}$ and total $\mathrm{N}$ to a depth of $1 \mathrm{~m}$. These data are presented in detail by Moraes et al. (1996). Briefly, five samples were collected in July 1992 from pits or with soil corers. Density was measured in volumetric $5-\mathrm{cm}$ dia metal cylinders collected from the walls of soil pits and dried at $105^{\circ} \mathrm{C} . \mathrm{pH}$ was determined in water (2.5:1) on air dried soil. Total $\mathrm{C}$ and $\mathrm{N}$ were determined on a Perkin-Elmer 2400 Elemental Analyzer from subsamples dried to $60^{\circ} \mathrm{C}$. Soil for texture determination was analyzed by the hydrometer method after digestion of the organic matter with $\mathrm{H}_{2} \mathrm{O}_{2}$ and dispersion with hexametaphosphate. Soils from the new pasture were collected at intervals from 2 months before cutting to 17 months after burning and analyzed in the same way.

Soils for net and gross mineralization and net nitrification were collected from each site in the chronosequence on 10 May 1993. Samples from the forest and new pasture were collected 2 months before cutting (27 April 1994), $5 \mathrm{~d}$ after burning (15 September 1994) and 1.5 months after burning (22 October 1994). The new pasture was also sampled 8.5 months after burning (26 May 1995). We used five samples collected from $0-5 \mathrm{~cm}$ with a $5-\mathrm{cm}$ dia corer. We selected $0-5$ $\mathrm{cm}$ because we have data that indicate that rates of net $\mathrm{N}$ mineralization are greatest at the surface and are highly indicative of rates at greater depths (Piccolo et al., 1994, Neill et al., 1995). Measurement of potential rates in laboratory incubations allowed us to compare patterns of gross and net rates from different sites without the large variability in moisture content that we have found accompanies a variety of in situ incubation techniques (Piccolo et al., 1994). Soils were mixed and roots were removed. Soils were refrigerated after collection, transported on ice to Woods Hole in sealed bags and stored for $1-3$ weeks at $4^{\circ} \mathrm{C}$ before measurements were made.

Soil inorganic $\mathrm{N}$ concentrations were measured by extraction with $2 \mathrm{~N} \mathrm{KCl}$ for $24 \mathrm{~h}$. Potential net mineralization and net nitrification rates were determined in $7 \mathrm{~d}$ laboratory incubations at $25^{\circ} \mathrm{C}$ on five soil samples collected at each date. Net mineralization and net nitrification rates were calculated from differences in $\mathrm{NH}_{4}^{+}$and $\mathrm{NO}_{3}^{-}$concentrations in $\mathrm{KCl}$ extracts before and after incubation. $\mathrm{NH}_{4}^{+}$and $\mathrm{NO}_{3}^{-}$were measured on an Alpkem autoanalyzer by phenol-hypochlorite and $\mathrm{Cd}$ reduction methods respectively.

Gross mineralization and gross nitrification were measured on the same mixed soil samples using pool dilution methods. Initial $\mathrm{NH}_{4}^{+}$and $\mathrm{NO}_{3}^{-}$concentrations were used to calculate the addition of 99 at $\%$ $\left({ }^{15} \mathrm{NH}_{4}\right)_{2} \mathrm{SO}_{4}$ or $K^{15} \mathrm{NO}_{3}$ required to contain at least $100 \mu \mathrm{g} \mathrm{N}$ and to enrich the soil inorganic $\mathrm{N}$ pool to 
approximately $300 \%$. This required raising soil inorganic $\mathrm{N}$ content by $\sim 1 \%$ and avoided artifacts of large artificial increases in the inorganic $\mathrm{N}$ pool. ${ }^{15} \mathrm{~N}$-labeled $\mathrm{NH}_{4}^{+}$or $\mathrm{NO}_{3}^{-}$was added to 5 pairs of samples. One sample of each pair was extracted immediately; the other was extracted after a $25-\mathrm{h}$ incubation at $25^{\circ} \mathrm{C}$. A subsample of the extract was analyzed for inorganic $\mathrm{N}$ and a subsample was diffused onto acidified filter disks to capture the ${ }^{15} \mathrm{~N}$ (Brooks et al., 1989). Ammonium was collected by adding $\mathrm{MgO}$. Nitrate was collected by adding $\mathrm{MgO}$ to remove the $\mathrm{NH}_{4}^{+}$, then adding Devarda's alloy to reduce the $\mathrm{NO}_{3}^{-}$to $\mathrm{NH}_{4}^{+} \cdot{ }^{15} \mathrm{~N}$ on the filters was determined on a Finnigan 251 isotope ratio mass spectrometer. Equations from Kirkham and Bartholomew (1954) were used to calculate gross $\mathrm{NH}_{4}^{+}$ and $\mathrm{NO}_{3}^{-}$production rates.

Means comparisons were done with Bonferroni $t$ tests using the GLM procedure of SAS with a significance level of 0.05 .

\section{Results}

In the chronosequence, bulk density ranged from $1.20-1.48 \mathrm{~g} \mathrm{~cm}^{-3}$ (Table 1). Density tended to be higher in the pastures but was significantly greater only in the 10-yr-old pasture. In the new pasture, density did not change immediately after the burn (Table 1). Resampling $3.5 \mathrm{yr}$ after burning showed that density had increased slightly $\left(1.17 \pm 0.05 \mathrm{~g} \mathrm{~cm}^{-3}\right)$ but was not statistically different from the value before cutting. Soil $\mathrm{pH}$ in the chronosequence was higher in pastures compared with the original forest (Table 1). The new pasture showed a similar pattern, with higher $\mathrm{pH} 1.5$ and 17 months after the burn. Soil C and N concentrations showed no significant trend in the chronosequence or in the new pasture (Table 1).
Soil moisture contents in the chronosequence were greater in the pastures than in the forest $(p<0.05)$ but the range of variation at this one sampling date was small (19.1\% in forest, $20.1-22.0 \%$ in pastures). In the new pasture, soil moisture contents varied over a wider range (15.1-20.5\%), but moisture content in the new pasture was never statistically different from moisture content in the forest on the same date.

In the chronosequence, pasture soils had higher extractable $\mathrm{NH}_{4}^{+}$concentrations, and $\mathrm{NH}_{4}^{+}$increased with pasture age (Table 2). Soil extractable $\mathrm{NO}_{3}^{-}$concentrations showed the opposite pattern, with lower $\mathrm{NO}_{3}^{-}$in pastures compared with forest and decreasing $\mathrm{NO}_{3}^{-}$concentrations with pasture age (Table 2). Ammonium concentrations at four dates over a year in the reference forest ranged from 1.5 to $8.8 \mu \mathrm{g} \mathrm{N} \mathrm{g}^{-1}$ dry soil and were highest in April (Table 2). Forest $\mathrm{NO}_{3}^{-}$concentrations ranged from 10.0 to $16.5 \mu \mathrm{g} \mathrm{N} \mathrm{g}^{-1}$ dry soil and showed little seasonal pattern, but were always greater than $\mathrm{NH}_{4}^{+}$concentrations (Table 2). Ammonium and $\mathrm{NO}_{3}^{-}$concentrations in the new pasture before cutting and burning were similar to amounts in the forest (Table 2). $\mathrm{NH}_{4}^{+}$concentrations showed large and significant increases after the burn but returned to levels like the reference forest by May (Table 2). $\mathrm{NO}_{3}^{-}$concentrations were higher in the new pasture than in the forest in September and October after burning but were more variable than $\mathrm{NH}_{4}^{+}$and did not differ statistically from the forest or among sampling times (Table 2).

In the chronosequence, net mineralization and net nitrification rates were higher in the forest than in the pastures (Table 2). Net nitrification rates exceeded net mineralization rates as the relatively high $\mathrm{NH}_{4}^{+}$pools, especially in the pastures, were converted to $\mathrm{NO}_{3}^{-}$ during the incubation. Gross mineralization rates were similar in forest, 4- and 10-yr-old pasture and lower in

Table 1

Soil characteristics at $0-5 \mathrm{~cm}$ in the chronosequence and in the new pasture before and after burning. Values are means \pm 1 standard error. Similar letters indicate mean values within the same columns of the chronosequence and new pastures experiments do not differ (Bonferroni $t$ tests, $p<0.05$ )

\begin{tabular}{|c|c|c|c|c|}
\hline & Density $\left(\mathrm{g} \mathrm{cm}^{-3}\right)$ & $\mathrm{pH}$ & Carbon $\left(\mathrm{mg} \mathrm{g}^{-1}\right)$ & Nitrogen $\left(\mathrm{mg} \mathrm{g}^{-1}\right)$ \\
\hline \multicolumn{5}{|l|}{ Chronosequence experiment } \\
\hline Forest & $1.20^{\mathrm{a}}$ & $4.94^{\mathrm{a}}$ & $16.08^{\mathrm{a}}$ & $1.30^{\mathrm{a}}$ \\
\hline 4-y pasture & $1.32^{\mathrm{a}}$ & $6.62^{\mathrm{b}}$ & $16.24^{\mathrm{a}}$ & $1.10^{\mathrm{a}}$ \\
\hline 10 -y pasture & $1.48^{\mathrm{b}}$ & $6.09^{\mathrm{b}}$ & $19.68^{\mathrm{a}}$ & $1.42^{\mathrm{a}}$ \\
\hline 21-y pasture & $1.24^{\mathrm{a}}$ & $5.69^{\mathrm{b}}$ & $19.30^{\mathrm{a}}$ & $1.26^{\mathrm{a}}$ \\
\hline \multicolumn{5}{|l|}{ New pasture experiment } \\
\hline 2 months before cut (Apr 94) & $1.08^{\mathrm{a}}$ & nd & nd & nd \\
\hline $4 \mathrm{~d}$ before burn (Sep 94$)$ & $1.05^{\mathrm{a}}$ & $4.40^{\mathrm{a}}$ & $12.31^{\mathrm{a}}$ & $1.08^{\mathrm{a}}$ \\
\hline $5 \mathrm{~d}$ after burn (Sep 94) & $1.07^{\mathrm{a}}$ & $4.79^{\mathrm{ab}}$ & $13.50^{\mathrm{a}}$ & $1.28^{\mathrm{a}}$ \\
\hline 1.5 months after burn (Oct 94) & nd & $5.77^{\mathrm{b}}$ & $17.65^{\mathrm{a}}$ & $1.28^{\mathrm{a}}$ \\
\hline 17 months after burn (Feb 96) & nd & $5.67^{\mathrm{b}}$ & $22.90^{\mathrm{a}}$ & $1.70^{\mathrm{a}}$ \\
\hline
\end{tabular}

nd $=$ not determined 
Table 2

Inorganic $\mathrm{N}$ concentrations, mineralization and nitrification rates and turnover rates of $\mathrm{NH}_{4}^{+}$and $\mathrm{NO}_{3}^{-}$in a chronosequence and before and after clearing and burning at Nova Vida. Similar letters indicate mean values within same columns of the chronosequence and new pastures experiments do not differ (Bonferroni $t$-tests, $p<0.05$ )

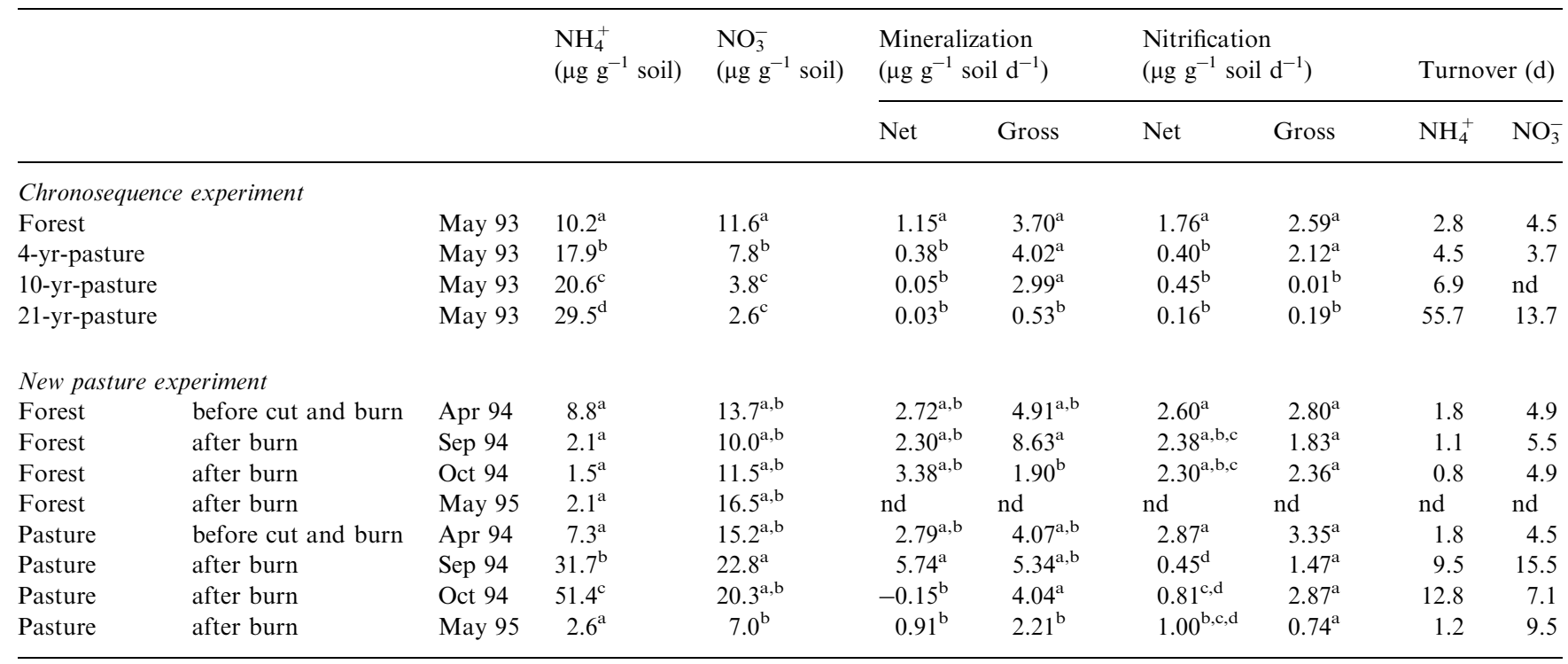

nd $=$ not determined

the oldest pasture (Table 2). Gross mineralization was approximately $3 \times$ net mineralization rate in the forest and many times net $\mathrm{N}$ mineralization rates where net rates were near zero (Table 2). Turnover times for the $\mathrm{NH}_{4}^{+}$pool ranged from $2.8 \mathrm{~d}$ in the forest to $55.7 \mathrm{~d}$ in the 21-yr-old pasture. Gross nitrification rates were similar in forest and 4-yr-old pasture and lower in 10and 21-yr-old pastures (Table 2). Soil $\mathrm{NO}_{3}^{-}$turnover times ranged from $3.7 \mathrm{~d}$ in the 4-yr-old pasture to 13.7 $\mathrm{d}$ in the 21-yr-old pasture. Measured gross nitrification in the 10-yr-old pasture was actually lower than measured net nitrification. This was probably associated with errors of measuring the change in total $\mathrm{NO}_{3}^{-}$ concentrations in 1-d incubations in pasture soils with low initial $\mathrm{NO}_{3}^{-}$concentrations. $\mathrm{NO}_{3}^{-}$turnover was not calculated for this pasture.

In the forest of the new pasture experiment, net mineralization rates were similar across the sampling dates (Table 2). Gross mineralization rates were more variable than net rates and declined from September to October. In the new pasture, net mineralization rates declined from September to October after the burn, but gross rates were similar among dates (Table 2). In the forest, neither net nor gross nitrification were different among dates and net and gross rates were similar (Table 2). In the new pasture, net nitrification rates decreased in the 2 months after the burn but gross nitrification rates were variable and showed no trend (Table 2). There were two instances where measured gross mineralization rates (September, forest) or gross nitrification rates (May, new pasture) were slightly lower than net rates but these were within the variability of gross rate measurements. Turnover of $\mathrm{NH}_{4}^{+}$in the new pasture ranged from $1.8 \mathrm{~d}$ before the burn, increased to $9.5-12.8 \mathrm{~d}$ in the first 2 months after the burn, primarily because of higher $\mathrm{NH}_{4}^{+}$concentrations, then decreased to $1.2 \mathrm{~d}$ after 8 months, as $\mathrm{NH}_{4}^{+}$concentrations decreased.

Soil moisture content was negatively correlated with net nitrification in the chronosequence $(p=0.010$, d.f. $=1,11)$ because the forest was drier and had higher net nitrification. Moisture was not related to net mineralization, gross mineralization or gross nitrification in the chronosequence or to net or gross mineralization or nitrification in the new pasture experiment.

\section{Discussion}

The patterns of $\mathrm{NH}_{4}^{+}$and $\mathrm{NO}_{3}^{-}$concentrations and net mineralization and net nitrification rates in soils of the chronosequence were consistent with previous studies from Rondônia that indicated: (1) $\mathrm{NH}_{4}^{+}$generally dominates pasture inorganic $\mathrm{N}$ pools, (2) forest inorganic $\mathrm{N}$ pools are either dominated by $\mathrm{NO}_{3}^{-}$or contain $\mathrm{NH}_{4}^{+}$and $\mathrm{NO}_{3}^{-}$in roughly equal proportions and (3) net mineralization and net nitrification rates are lower in pasture than in forest and rates tend to decline with pasture age (Neill et al., 1995). These findings, which tend to be consistent across a range of sites and soils (Neill et al., 1997; Verchot, pers. comm.), suggest that pasture formation and aging lead to a general slowing of the rate of soil $\mathrm{N}$ turnover. 
The rates of gross $\mathrm{N}$ mineralization and nitrification we measured only partially supported this view. Both gross and net mineralization and nitrification were lower in the 21-yr-old pasture, consistent with the conclusion that less $\mathrm{N}$ is cycling in older pastures. Gross nitrification was also much lower in the 10 -yr-old pasture, indicating that $\mathrm{N}$ availability had fallen below the amount needed to maintain nitrifiers. But the 4and 10 -yr-old pastures had rates of gross mineralization that were similar to the forest. The relatively high ratios of gross-to-net mineralization in these intermediate-aged pastures indicated that more of the mineralized $\mathrm{N}$ was immobilized and not measured by the net mineralization incubations. These patterns suggest that in forest, where litter is actively recycled at the soil surface, $\mathrm{C}$ availability in the mineral soil is low but soil $\mathrm{N}$ availability and hence nitrification rates are high. In pastures, surface litter inputs decrease but soil subsurface inputs of labile $\mathrm{C}$ increase. This has the effect in pasture soils of first reducing net $\mathrm{N}$ availability, then gross nitrification, and eventually gross $\mathrm{N}$ mineralization.

Several other lines of evidence suggest that there are $\mathrm{C}$ inputs to soil from vigorously-growing grasses and these can maintain microbial growth and turnover in intermediate-aged pastures. During the first decade of pasture development, grass-derived soil $\mathrm{C}$ rapidly replaces forest-derived soil $\mathrm{C}$, while maintaining or slightly increasing total soil C stocks (Neill et al., 1996). Microbial biomass $\mathrm{C}$ and $\mathrm{N}$ and soil respiration are also higher in 3- to 9-yr-old pastures than in the original forest or in older pastures (Feigl, unpubl. data; Steudler et al., unpubl. data). Grass-derived C makes up the majority $(>70 \%)$ of microbial respiration in pastures 3-yr-old and older (Neill et al., 1996), indicating inputs of grass $\mathrm{C}$ to soil rather than the degradation of residual labile forest SOM fuel microbial activity in intermediate-aged pastures.

The factors that result in the decline of $\mathrm{N}$ cycling but not soil $\mathrm{C}$ and $\mathrm{N}$ stocks in the oldest pasture are not known, but several mechanisms are possible. One is that microbes gradually rework SOM in pastures to more recalcitrant forms that cycle $\mathrm{N}$ more slowly compared with SOM in the original forest. Another is that pasture grasses sequester a large proportion of total soil $\mathrm{N}$ stocks in living belowground biomass that turns over relatively slowly. We know that the $\mathrm{C}$-to- $\mathrm{N}$ ratio of SOM remains relatively constant after pasture installation (Feigl et al., 1995), but we have not examined other aspects of SOM quality or measured changes in below-ground biomass and biomass $\mathrm{N}$ stocks that would allow evaluation of these hypotheses. It is interesting that rates of soil $\mathrm{NH}_{4}^{+}$and $\mathrm{NO}_{3}^{-}$ turnover were somewhat slower than reported for temperate forest and grassland soils (Davidson et al., 1990). This may be because limitation of plants and potentially microbes by other nutrients (e.g., P), allows for increased inorganic $\mathrm{N}$ pools and less microbial demand for $\mathrm{N}$ in these soils. $\mathrm{P}$ additions stimulate grass growth and increase microbial biomass $\mathrm{C}$ and $\mathrm{N}$ in these soils (Gonçalves and Oliveira, 1984; Feigl, unpubl. data).

Slash burning in Amazonian forests is accompanied by a relatively thorough consumption of leaves and other sources of high quality organic material and a large input to soils of low quality, high C-to-N coarse woody debris (Kauffman et al., 1995). This input was probably responsible for the $\mathrm{N}$ immobilization recorded by the net mineralization measurements 1.5 months after the burn. We expected but did not observe increases in net and gross mineralization and nitrification rates after the burn, perhaps because microbial communities were diminished by burning and took time to become reestablished. This absence of any increase in mineralization and nitrification rates suggests that the high $\mathrm{NH}_{4}^{+}$and $\mathrm{NO}_{3}^{-}$concentrations we observed immediately after burning were associated with the elimination of plant uptake, rather than acceleration of $\mathrm{N}$ cycling. This is also consistent with the fact that the high $\mathrm{NH}_{4}^{+}$and $\mathrm{NO}_{3}^{-}$concentrations disappeared by 8.5 months after the burn, when pasture grass had become established. In other tropical forest systems, the period of elevated soil $\mathrm{N}$ availability after clearing and burning can range from a few months (Matson et al., 1987) to several years (Uhl and Jordan, 1984) and depends on the timing of the regrowth of forest plants.

Our findings support the conclusion that $\mathrm{N}$ is relatively available in tropical moist forests and that forest soils mineralize and nitrify large amounts of $\mathrm{N}$ (Vitousek and Sanford, 1986). When forests are cleared for pasture, $\mathrm{N}$ cycling is maintained for a period of a decade or longer, but $\mathrm{N}$ turnover eventually slows in pasture soils. The changes in rates of $\mathrm{N}$ mineralization and nitrification that follow pasture creation have important regional implications because of their potential links to ecosystem $\mathrm{N}$ losses through leaching or gaseous emissions. As older pastures come to dominate deforested regions of the Amazon such as Rondônia, the total $\mathrm{N}$ cycled in soils of the region and the potential for regional $\mathrm{N}$ losses from soils are likely to decrease, but not as quickly as studies of net mineralization and net nitrification alone would indicate.

\section{Acknowledgements}

Funding for this study was provided by National Aeronautics and Space Administration, and by grants from the Texaco Foundation to the Marine Biological Laboratory. We thank João Arantes Jr. for his generosity in allowing us to work at Fazenda Nova Vida. 
Brigitte Feigl, José Cardozo, João Luis Esteves (INCRA-RO), EMATER-RO, EMBRAPA-RO and the office of the Secretary of Agriculture, Rondônia all provided valuable assistance. The comments of $\mathrm{J}$. Schimel greatly improved this paper.

\section{References}

Bastos, T.X., Diniz, T.D. de A.S., 1982. Avaliação de clima do Estado de Rondônia para desenvolvimento agrícola. Boletim de pesquisa, No. 44 Belém, EMBRAPA-CPATU.

Brooks, P.D., Stark, J.M., McInteer, B.B., Preston, T., 1989. Diffusion method to prepare soil extracts for automated nitrogen15 analysis. Soil Science Society of America Journal 53, 17071711.

Davidson, E.A., Stark, J.M., Firestone, M.K., 1990. Microbial production and consumption of nitrate in an annual grassland. Ecology 71, 1968-1975.

Davidson, E.A., Hart, S.C., Shanks, C.A., Firestone, M.K., 1991. Measuring gross nitrogen mineralization, immobilization and nitrification by ${ }^{15} \mathrm{~N}$ isotopic pool dilution in intact soil cores. Journal of Soil Science 42, 335-349.

Feigl, B.J., Melillo, J.M., Cerri, C.C., 1995. Changes in the origin and quality of soil organic matter and its size fractions after deforestation for pasture introduction in Rondônia (Brazil). Plant and Soil 175, 21-29.

Gonçalves, C.A., Oliveira, J.R. da C., 1984. Avaliação de sete gramineas forrageiras tropicais em Porto Velho, RO. Buletim de Pesquisa No. 2, Empresa Brazileira de Pesquisa Agropecuária, Porto Velho, RO.

INPE (Instituto Nacional de Pesquisas Espaciais), 1998. Deflorestamento Amazônia 1995-1997. São José dos Campos, São Paulo.

Kauffman, J.B., Cummings, D.L., Ward, D.E., Babbit, R., 1995. Fire in the Brazilian Amazon: biomass, nutrient pools and losses in slashed primary forests. Oecologia 140, 397-408.

Kirkham, D., Bartholomew, W.V., 1954. Equations for following nutrient transformations in soils, utilizing tracer data. Soil Science Society of America Proceedings 18, 33-34.
Matson, P.A., Vitousek, P.M., Ewel, J.J., Mazzarino, M.J., Robertson, G.P., 1987. Nitrogen transformations following tropical forest felling and burning on a volcanic soil. Ecology 68, 491502 .

Montagnini, F., Buschbacher, R., 1989. Nitrification rates in two undisturbed tropical rain forests and three slash-and-burn sites of the Venezuelan Amazon. Biotropica 21, 9-14.

Moraes, J.F.L., Volkoff, B., Bernoux, M., Cerri, C.C., 1996. Soil properties under Amazon forest and changes due to pasture installation in Rondônia (Brazil). Geoderma 70, 63-81.

Nadelhoffer, K.J., Aber, J.D., Melillo, J.M., 1983. Leaf-litter production and soil organic matter dynamics along a nitrogen-availability gradient in southern Wisconsin (USA). Canadian Journal of Forest Research 13, 12-21.

Neill, C., Piccolo, M.C., Steudler, P.A., Melillo, J.M., Feigl, B., Cerri, C.C., 1995. Nitrogen dynamics in soils of forests and active pastures in the western Brazilian Amazon Basin. Soil Biology \& Biochemistry 27, 1167-1175.

Neill, C., Fry, B., Melillo, J.M., Steudler, P.A., Moraes, J.F.L., Cerri, C.C., 1996. Forest- and pasture-derived carbon contributions to carbon stocks and microbial respiration of tropical pasture soils. Oecologia 107, 113-119.

Neill, C., Piccolo, M.C., Cerri, C.C., Steudler, P.A., Melillo, J.M., Brito, M., 1997. Net nitrogen mineralization and net nitrification rates in soils following deforestation for pasture across the southwestern Brazilian Amazon Basin landscape. Oecologia 110, 243252.

Piccolo, M.C., Neill, C., Cerri, C.C., 1994. Net nitrogen mineralization and net nitrification along a tropical forest-to-pasture chronosequence. Plant and Soil 162, 61-70.

Reiners, W.A., Bouwman, A.F., Parsons, W.F.J., Keller, M., 1994. Tropical rain forest conversion to pasture: changes in vegetation and soil properties. Ecological Applications 4, 363-377.

Uhl, C., Jordan, C.F., 1984. Succession and nutrient dynamics following forest cutting and burning in Amazonia. Ecology 65, 14761490.

Vitousek, P.M., Sanford, R.L., Jr., 1986. Nutrient cycling in moist tropical forest. Annual Review of Ecology and Systematics 17, $137-167$. 